Int. J. Morphol.,

32(2):671-677, 2014

\title{
Morphology of the Physiological Apical Foramen in Maxillary and Mandibular First Molars
}

\author{
Morfología del Foramen Fisiológico Apical en Primeros Molares Maxilares y Mandibulares
}

Abarca, J. ${ }^{* * * *}$; Zaror, C. ${ }^{* * *}$; Monardes, H. ${ }^{* * * *}$; Hermosilla, V. ${ }^{* * * * * *}$; Muñoz, C. ${ }^{* * * * * *}$ \& Cantin, M.**************

ABARCA, J.; ZAROR, C.; MONARDES, H.; HERMOSILLA, V.; MUÑOZ, C. \& CANTIN, M. Morphology of the physiological apical foramen in maxillary and mandibular first molars. Int. J. Morphol., 32(2):671-677, 2014.

SUMMARY: Information regarding the anatomy of the physiological apical foramen is limited. Knowing its diameter and shapes contributes to clinical work, specifically to the cleaning and shaping of the apical third. The aim of this ex vivo study was to determine the minimum and maximum diameters and shape of the physiological apical foramen in the roots of maxillary and mandibular first molars. A descriptive study was conducted on 89 recently extracted first molars. Roots 3-5 mm from the apex were sectioned and prepared for analysis at 40x magnification. The minimum and maximum diameters of each physiological foramen were measured using the program Motic Images plus 2.0 ML. The shape of the foramina, classified as round, oval or irregular, was determined by the difference between the maximum and minimum diameters. A total of 174 physiological foramina were analyzed. The average of the minimum and maximum diameters was between $0.24-0.33 \mathrm{~mm}$ in maxillary first molars and between $0.25-0.33 \mathrm{~mm}$ in mandibular first molars. In maxillary molars, the most common shape of the foramen was oval (50\%), then irregular (32\%), then round (18\%). In mandibular molars, the oval shape was also the most frequent (59\%), followed by irregular (23\%) and round (18\%). The findings of this study regarding the morphology of physiological apical foramina in first molars make it easier for the operator to choose the appropriatelysized instruments to perform endodontic therapy successfully.

KEY WORDS: Physiological Foramen; Apical constriction; Root apex; Apical diameter; Foraminal morphology; Permanent first molar.

\section{INTRODUCTION}

In addition to diagnosis and treatment planning, knowledge of the morphology of the root canal system and its variations are a basic requirement for endodontic success (Vertucci, 2005) since adequate debridement and three-dimensional obturation are based on this information (Fan et al., 2008). The aim of root canal shaping during instrumentation is, in addition to the elimination of the pulp tissue or pathogenic microorganisms, a shaping which is adequate for its obturation and sealing (Hassanien $e t$ al., 2008; Martos et al, 2010).

The apical region of the root canal may be considered critical territory for microorganisms, the immune response of the host and for endodontists from a clinical point of view, where it would be ideal if all or most of the infected tissue were eliminated from the canal system and its physiological foramina (Hülsmann \& Schäfer, 2009). The physiological foramen or apical constriction of the root corresponds anatomically to the end of the root canal, which contains the minimum diameter or narrowest part of the root canal, where the cementodentinal junction is located.

Typically, it has been described and it is assumed that the physiological foramen is round, although studies show that it can vary to ovals, with the maximum diameter presenting in the buccolingual or bucco-palatal aspect (Martos et al.), or irregular shapes. The morphology of

* Alumno Programa Magister en Odontología, Universidad de La Frontera, Temuco,Chile.

** Facultad de Odontología, Universidad San Sebastián, Puerto Montt, Chile.

*** Departamento de Odontopediatría y Ortodoncia, Facultad de Odontología, Universidad de la Frontera, Temuco, Chile.

**** Facultad de Odontología, Universidad San Sebastián, Santiago, Chile.

****** Alumna Programa de Postítulo en Endodoncia, Facultad de Odontología, Universidad San Sebastián, Santiago, Chile.

******* Programa de Doctorado en Ciencias Morfológicas. CIMA Research Group, Facultad de Odontología, Universidad de la Frontera, Temuco, Chile.

******** Center of Research in Biomedical Science, Universidad Autónoma de Chile, Temuco, Chile. 
the physiological foramen is directly related to the morphology that the most apical part of the root canal will adopt, since the round foramen will be shaped by a conical canal, whereas the oval foramen, with a larger and smaller diameter, will be shaped by a canal with parallel walls (Dummer et al.; Briceño et al., 2004), and this shape becomes even more complex in irregularly-shaped foramina.

It is impossible to determine the apical region of the root canal and the shape of the physiological apical foramen clinically and accurately. Among the methods used to study its specific morphology, micro-CT provides a detailed, apical three-dimensional view and performs in vivo and ex vivo cuts, but its scope is limited due to the equipment needed and the high cost, disadvantages overcome by the microscopic technique, where the apical area can be observed under different magnifications in teeth ex vivo either directly or using the cross and longitudinal section of the root to study the shape of the canal up to the foramen, with this being a simpler, more reliable, reproducible and low-cost method (Meder-Cowherd et al., 2011; Ordinola-Zapata et al., 2013).

The difficulty in the elimination of the remaining bacteria from the apical third has been attributed to the narrowness of the canal, its complex morphology, wall parallelism and the creation of angles or spaces even after endodontic instrumentation (which is round), inadequate washing with irrigants, and variations in the root canal diameter (Saini et al., 2012). For a root canal treatment to be successful and predictable, the morphology of the apical region and its canals must be understood, particularly its starting point, the physiological foramen, since knowing its shape and morphological dimensions would be advantageous in determining the diameter of the final shaping in the endodontic treatment, and would ensure adequate cleaning and sealing (Fan et al.; Olson et al., 2008). The aim of this study was to determine and measure the minimum and maximum diameters and shape of the physiological apical foramen and to determine its shape in the roots of the maxillary and mandibular first molars.

\section{MATERIAL AND METHOD}

An ex vivo descriptive study was conducted on 89 recently extracted first molars from a Chilean sample. Included were permanent maxillary and mandibular first molars with full apical and root formation. All the teeth were extracted due to periodontal disease, pulp or for prosthetic reasons. Teeth with crown destruction, previous endodontics, root resorptions or root fissures were excluded.
Preparation of the samples. After extraction, the teeth were washed under running water and cleaned manually with a universal curette to remove particles or adhered periodontal tissue, and preserved in physiological saline solution. The mesial vestibular, distal vestibular and palatal roots of maxillary molars as well as the mesial and distal roots in the mandibular molars were cross-sectioned to an approximate distance of 3 to $5 \mathrm{~mm}$ from the anatomical apex with a diamond disc under constant refrigeration with physiological saline and at a low speed. The root sections were submerged in a solution of $5.25 \%$ sodium hypochlorite for 24 hours to disinfect their surfaces and remove the remaining organic tissue.

Finally, they were submerged in hydrogen peroxide for 1 hour, washed under running water and dried with gauze and pressurized air. In those cases where residual soft tissue remained around and in the area of the apical foramen, it was removed with a $\mathrm{K} \# 6$ file (Dentsply Maillefer, Ballaigues, Switzerland), working towards the anatomical apical foramen via magnification.

The root pieces were placed on a slide, positioned so that the anatomical foramen was parallel to the magnifying lens of the microscope, and the four faces of the root were observed in order to explore the entire root apex. The anatomical foramen (major apical foramen) was located on the external surface and the physiological foramen (minor apical foramen or apical constriction) corresponded to the region of the apical foramen with the minimum or most internal diameter.

Photographs were taken (Motic Cam) of each sample under a 40X magnification, and measurements of the maximum and minimum diameters were taken in each physiological foramen using the program Motic Images plus 2.0 ML. The measurements were taken in millimeters and adjusted to three digits after the decimal as can be seen in Figure 1. In every case, the foramen was considered physiological when the diameter was $\geq 0.10 \mathrm{~mm}$. When it measured less than $0.10 \mathrm{~mm}$, it was considered an accessory foramen.

The shape of the physiological foramina was determined by the difference between their maximum and minimum diameters. It was classified as round when the difference was equal to or less than $0.02 \mathrm{~mm}$ and oval when the difference was greater than $0.02 \mathrm{~mm}$. The cases that did not follow this pattern were considered irregular (Briceño et al.).

Calibration. Prior to the observation of the samples, theoretical training was undertaken, in which both examiners 


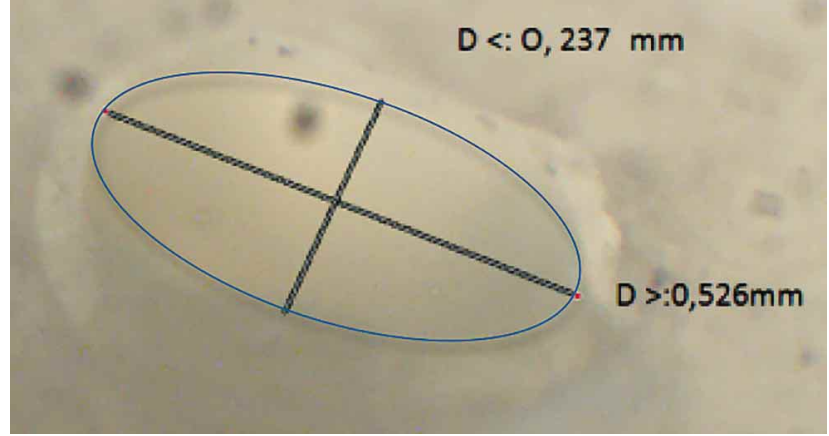

Fig. 1. Measurement technique used to determine the maximum and minimum diameters of the physiological foramen of maxillary and mandibular first molars.

agreed on the method of measurement. Afterward, a calibration was conducted, in which each observer measured 15 foramina randomly in different rooms, but maintaining the conditions of time, light and screen resolution. Ten days later the procedure was repeated under the same conditions. The intraexaminer and interexaminer agreement was calculated using the interclass correlation coefficient (ICC) with the statistical program EPIDAT 4.0. The intraexaminer ICC was 0.997 and the interexaminer ICC was 0.998 , indicating a high level of agreement.

Plan of analysis. The collected data were entered on an Excel spreadsheet (Microsoft Office 2010). A descriptive analysis (mean \pm SD) and exploratory analysis (ranges) were performed using SPSS v. 20. The results were expressed through tables and graphs showing frequency distribution and summary measures.

\section{RESULTS}

A total of 174 physiological apical foramina belonging to 41 maxillary first molars and 48 mandibular first molars were observed. The topographical root distribution of the foramina for the sample was 20\% maxillary mesiobuccal, $17 \%$ maxillary distobuccal, $18 \%$ palatal, $23 \%$ mandibular mesial and $22 \%$ mandibular distal.

The average of the minimum and maximum diameters of the physiological foramen of the maxillary molars was 0.24 and $0.34 \mathrm{~mm}$, and in the mandibular molars 0.25 and 0.33 $\mathrm{mm}$, respectively. Table I shows the average apical diameter, expressed as the maximum diameter (length) and minimum diameter (width) of the physiological foramen of each of the roots observed.

The most common foraminal morphology in the root apices of the maxillary first molars was oval (50\%), followed by irregular (32\%) and round (18\%) (Fig. 2). In the first mandibular molars, the oval shape was also the most frequently observed (59\%), whereas $23 \%$ were irregular and $18 \%$ round (Fig. 3). Figure 4 indicates the shape of the physiological foramina and its frequency of presentation in each of the roots of the maxillary and mandibular molars.

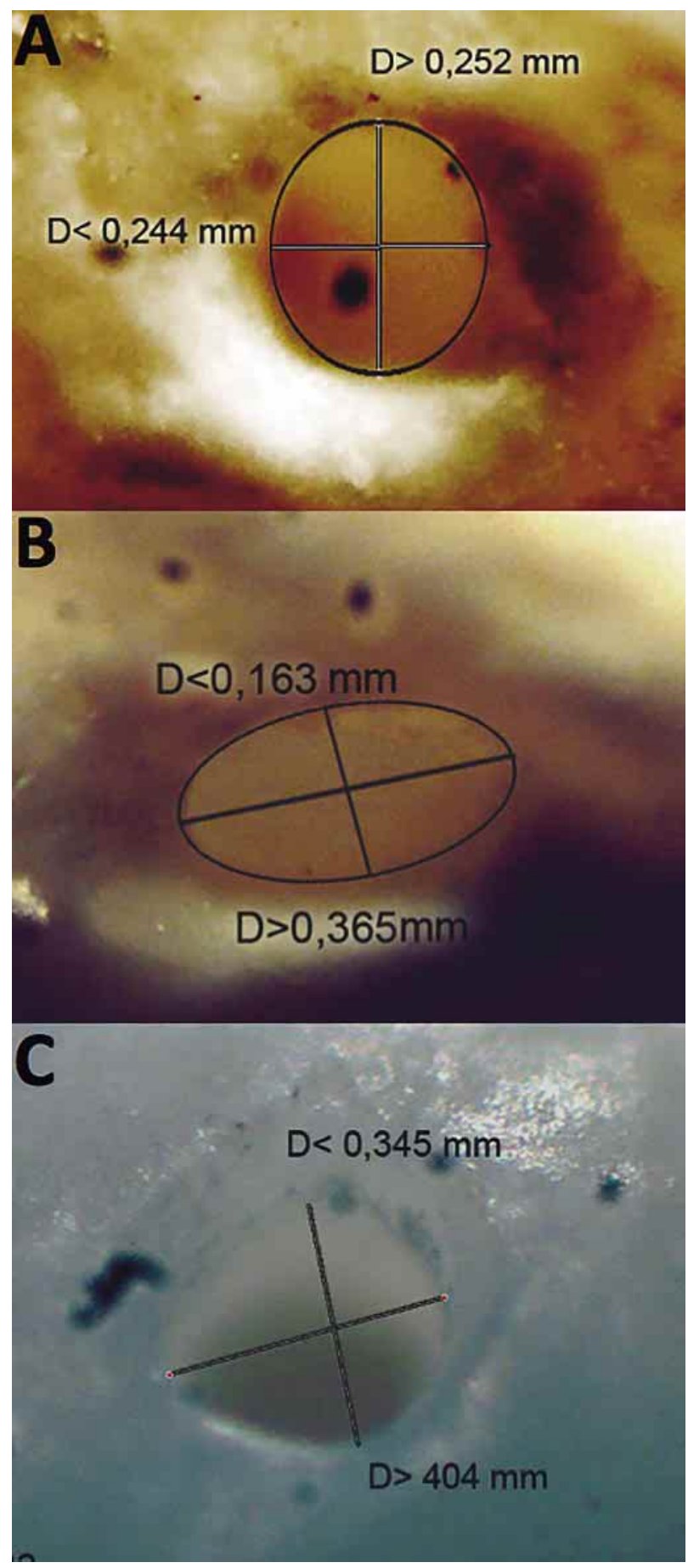

Fig. 2. Shape of physiological foramina in apices of mesial vestibular, distal vestibular and palatal roots in maxillary first molars. A) Round, B) Oval and C) Irregular. 
Table I. Measurements of central tendency of the maximum and minimum diameters of the physiological foramen of each root (all dimensions in millimeters).

\begin{tabular}{|c|c|c|c|c|c|c|c|c|c|c|}
\hline Root & \multicolumn{2}{|c|}{$\begin{array}{c}\text { Mesiobuccal } \\
\mathbf{n}=\mathbf{3 5}\end{array}$} & \multicolumn{2}{|c|}{$\begin{array}{c}\text { Distobuccal } \\
\mathbf{n}=\mathbf{3 0}\end{array}$} & \multicolumn{2}{|c|}{$\begin{array}{c}\text { Palatal } \\
\mathbf{n}=\mathbf{3 2}\end{array}$} & \multicolumn{2}{|c|}{$\begin{array}{c}\text { Mesial } \\
n=39\end{array}$} & \multicolumn{2}{|c|}{$\begin{array}{l}\text { Distal } \\
n=38\end{array}$} \\
\hline Diameter & Major & Minor & Major & Minor & Major & Minor & Major & Minor & Major & Minor \\
\hline Minimum & 0.134 & 0.079 & 0.127 & 0.104 & 0.152 & 0.107 & 0.136 & 0.109 & 0.095 & 0.09 \\
\hline Maximum & 0.709 & 0.531 & 0.909 & 0.830 & 0.720 & 0.485 & 0.795 & 0.436 & 0.854 & 0.527 \\
\hline Mean & 0.307 & 0.230 & 0.320 & 0.248 & 0.400 & 0.272 & 0.311 & 0.227 & 0.360 & 0.266 \\
\hline SD & 0.124 & 0.087 & 0.177 & 0.169 & 0.153 & 0.097 & 0.136 & 0.085 & 0.154 & 0.112 \\
\hline
\end{tabular}
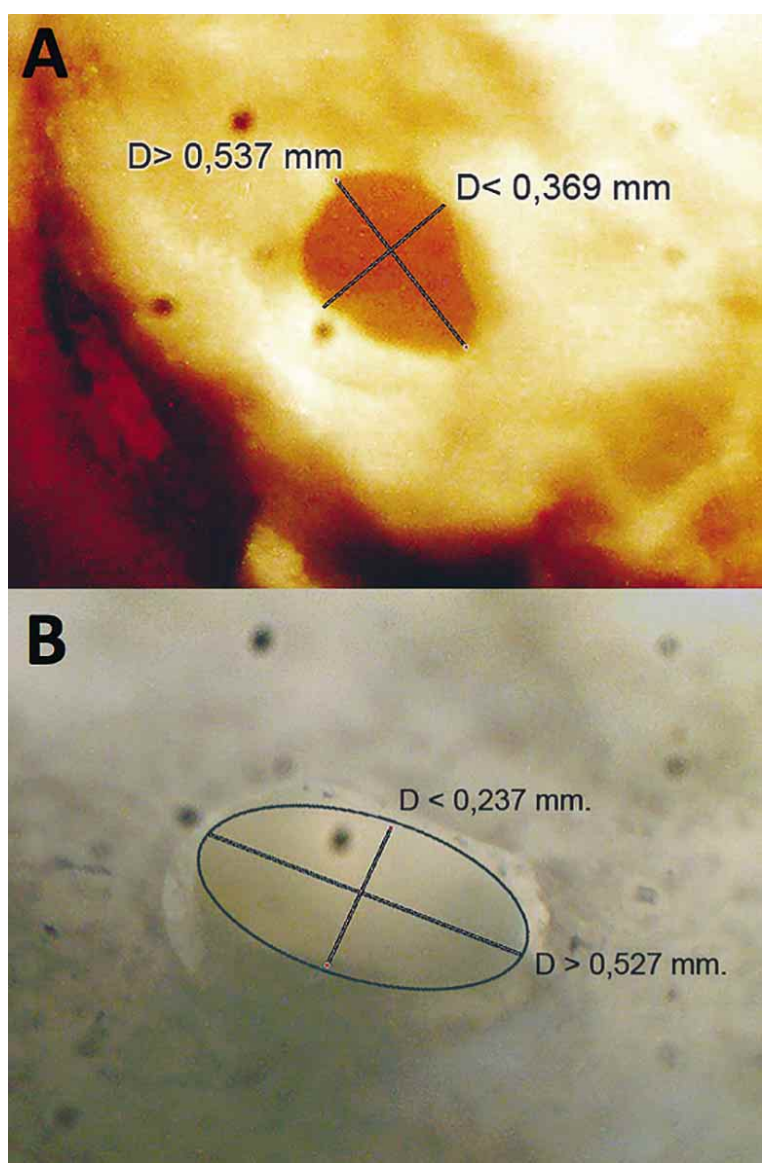

Fig. 3. Shape of physiological foramina in apices of mesial and distal root in mandibular first molars. A) Irregular and B) Oval.

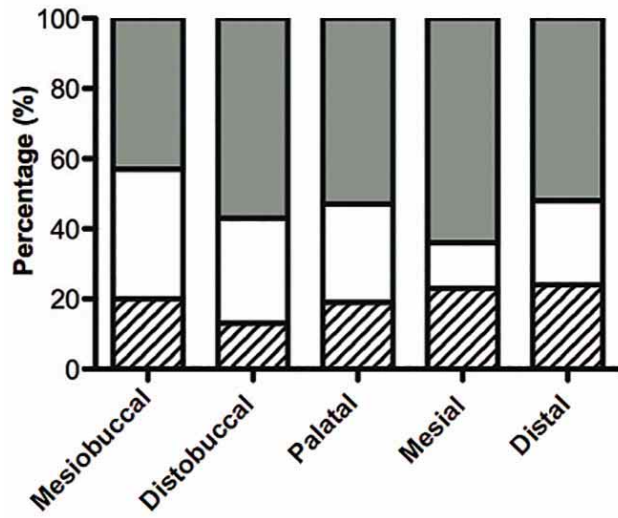

Oval shape

Irregular shape

ZבA

Round shape
Fig. 4. Relative frequency of the shape of the physiological foramen according to root.
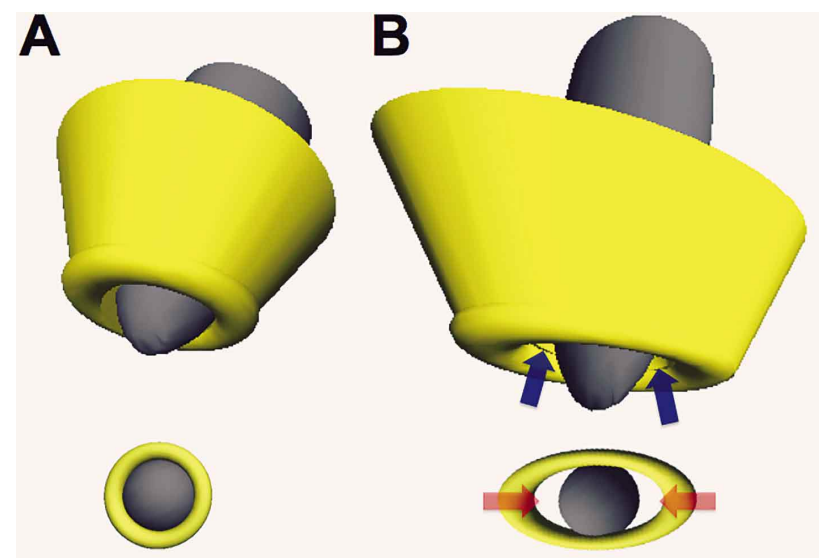

Fig. 5. Three-dimensional reconstruction of the root apical region and shape of the physiological foramen. In A, a root with a conical canal can be seen that ends in a round physiological foramen constructed with the values of maximum and minimum diameters obtained from the MV25 sample, where when the positioning of a round endodontic instrument or one that generates a round preparation is simulated, it adapts completely to the physiological foramen. In B, a root with more parallel canal walls that end at an oval-shaped physiological foramen with the maximum and minimum diameter values obtained from the D35 sample, where when the positioning of a round endodontic instrument or one that generates a round preparation is simulated, it is only adapted to the most central area of the foramen, a limit due to its minimum diameter, leaving areas of the physiological foramen (blue arrows) uninstrumented, and spaces that can house remains of tissue and microorganisms (red arrows) that will then be able to access the periapical tissues. 


\section{DISCUSSION}

In clinical practice, the physiological foramen is the most consistent anatomical characteristic (Ponce \& Vilar Fernández 2003) and the point of reference as the apical endpoint in root canal treatment (Briceño et al.). It is a structure or region that the clinician cannot observe directly, highlighting its importance as more positional than morphological (Prabhakar et al., 2013), despite its relevance, which is consistent with the paucity of literature associated with the morphological characteristics of the foramen.

With respect to the diameter of the physiological foramina, we obtained an average measurement of the minimum and maximum diameters of the foramen of 0.24 and $0.34 \mathrm{~mm}$ in the roots of maxillary molars and of 0.25 and $0.33 \mathrm{~mm}$ in the mandibular molars, respectively, which is consistent with previous descriptions provided by Briceño et al. and Morfis et al. (1994), who reported average diameters of 0.20 and $0.26 \mathrm{~mm}$ for maxillary molars and 0.26 and $0.39 \mathrm{~mm}$ for mandibular molars (maximum and minimum, respectively). In a sample of 60 mandibular first molars from Koreans, Jeong et al. (2009) described values closely related to those found in our study regarding the physiological foramen of mandibular molars, with an average minimum diameter of $0.229 \pm 0.061 \mathrm{~mm}$ and maximum of $0.329 \pm 0.098 \mathrm{~mm}$ in the mesial foramen, and for the distal foramen a minimum of $0.288 \pm 0.073 \mathrm{~mm}$ and a maximum $0.375 \pm 0.082 \mathrm{~mm}$. By contrast, Arora \& Tewari (2009) reported a lower average value for these diameters $(0.171 \mathrm{~mm}$ and $0.24 \mathrm{~mm}$ in maxillary molars and 0.173 $\mathrm{mm}$ and $0.256 \mathrm{~mm}$ in mandibular molars). However, the specific results for each root continue to be similar to those found in this study (Arora \& Tewari; Briceño et al.).

The measurements obtained for the physiological foramina may be significant for clinical applications, such as the determination of endodontic instruments best suited to cleaning and shaping each root canal according to the average diameters. Thus for example, in this study the diameter of the apical foramina of maxillary and mandibular first molars varied between $0.22-0.40 \mathrm{~mm}$, which is why instrumentation with a \#15 or \#20 file, although ensuring the permeability of the canal and foramen, would be insufficient to instrument all the canal walls or physiological foramen in their true diameter. Therefore, it would require higher caliber instruments that could guarantee adequate extension and irrigation of the apical area, with a reduction in the residual or bacterial component remaining within the root canal system, thereby improving prognosis.
In terms of the physiological foramen, this was considered round when the difference between the maximum and minimum diameter was equal to or less than $0.02 \mathrm{~mm}$. This criterion, although arbitrary, was established as per the ISO standard for root canal instruments (Briceño et al.) We concur with Blaskovic-Subat et al. (1995) that the physiological apical foramen is not often round. We observed that the most common shape of apical foramina was oval, representing $50 \%$ of maxillary molars and $59 \%$ of mandibular molars. This is consistent with the descriptions by Arora \& Tewari, who indicated that the oval shape is found in $78 \%$ to $89 \%$ of the cases in different roots, whereas Briceño et al. have reported it with a frequency of $70 \%$. Jeong et al. have also reported that the oval shape is the most common in the physiological foramen $(69.93 \%)$ of mandibular first molars, followed by round and then irregular. These results make it possible to establish differences from the classic round shape described for these foramina, and which has been maintained by various authors, including Gani \& Virvician (1999), who found a greater frequency of round and irregular shapes in maxillary molars, with a predominance of the round shape in apical foramina of palatal and distobuccal roots and irregular in mesiobuccal roots. Martos et al. have also reported that the round shape was most common in maxillary molars at $67.6 \%$, followed by oval (19.4\%), asymmetric (7.7\%) and crescent-shaped (5.4\%); in mandibular molars it was also round with $56.1 \%$, followed by oval $(25.2 \%)$, asymmetric (12.9\%) and crescent-shaped (5.8\%). We can infer that there is no general pattern and the morphologies of the physiological foramen in a root present variations (as well as in the diameters). These variations may be due to differences in the methodology used to determine their morphology, age, sample size, influences of occlusion or other factors that could modify the results (Briceño et al.; Martos et al.; Ordinola-Zapata et al.). In this respect, the permanent remodeling of the root apex through cement apposition and resorption could interfere with and modify the results of the anatomical assessment (Martos et al.). In addition, it is unknown whether induced forces, as occurs with the dental movement resulting from orthodontic treatment, would alter the morphology of the apical third of the root canal, physiological and anatomical foramina. These conditions could not be controlled in the study.

The presence of a greater frequency of oval shapes in the physiological foramina has a direct impact on the endodontic clinic. Generally, penetration by the instruments is limited to the physiological foramen, and these instruments have a shape (round, quadrangular, triangu- 
lar, etc.) that will ultimately produce a round preparation, which would be adapted to the foramen (Fig. 5A); however, this instrument will not be adapted adequately to the constrictions it possesses and the gaps left by the oval (Fig. 5B), elliptical or irregular shape. Furthermore, the shape of the foramen may be indicative of the morphology of the canal (endpoint of the canal) nearest to the foramen, given that in the case of an oval foramen the canal will have parallel walls with a more rectangular canal or even a greater number of walls. This is more complicated in long and narrow canals, which are difficult to shape completely without perforating or weakening the root (Briceño et al.). This means that the instrument that enables preparation of the canal (round preparation) does not ensure (in the case of an oval shape) the complete modification of the morphology of the canal and physiological foramen to a round shape and will leave walls uninstrumented and areas of the foramen uncleaned (mainly the edges of the maximum diameter of the physiological foramen) (Fig. 5B). This in turn will leave the remaining tissues and microorganisms able to access the periapical tissues, being an important etiological factor in the development or persistence of periapical inflammation (mainly chronic inflammation).

Although there are other research methods, such as scanning electron microscopy or high-resolution tomography and $3 \mathrm{D}$ reconstruction, used to reduce the uncontrollable variables in the study and to increase measurement precision, these are complex to perform (Briceño et al.); by contrast, the methodology used in this study enabled accurate measurements of all the samples collected for this purpose in a simple way.

Knowledge of apical anatomy is necessary for the success of surgical and non-surgical endodontic treatment. Estimation of the diameter of the physiological foramen permits selection of the suitable instrument to penetrate the physiological foramen passively and achieve permeability in endodontic preparation. This means ensuring control of the passability of the foramen (Hülsmann \& Schäfer), as well as estimating the caliber to obtain its full preparation. The morphology of the physiological foramen is critical to endodontic treatment, since the instruments only allow one cleaning and round preparation; therefore, in order to ensure a correct cleaning and sealing of the canal and foramen, the morphology of the foramen should be modified towards the round type, or new techniques or instruments must be evaluated that can be adapted to non-round shapes.

The findings of this study with regard to the morphology of the apical foramina in first molars facilitate the selection of instruments of a caliber sufficient to the case, complementing this morphological knowledge with tools such as periapical x-rays, apex locators, tactile sensitivity and the ability of the operator to perform endodontic treatment successfully.

ABARCA, J.; ZAROR, C.; MONARDES, H.; HERMOSILLA, V.; MUÑOZ, C. \& CANTIN, M. Morfología del foramen fisiológico apical en primeros molares maxilares y mandibulares. Int. J. Morphol., 32(2):671-677, 2014.

RESUMEN: La información relacionada a la anatomía del foramen fisiológico apical es limitada. Conocer su diámetro y forma contribuye al trabajo clínico, específicamente en los procedimientos de limpieza y conformación del tercio apical. El objetivo de este estudio ex vivo fue determinar los diámetros menor, mayor y la forma del foramen fisiológico apical en las raíces de primeros molares maxilares y mandibulares. Se realizó un estudio descriptivo sobre 89 primeros molares recientemente extraídos. Se seccionaron las raíces a 3-5 mm del ápice y fueron preparadas para su análisis bajo magnificación de 40X. Se midieron los diámetros mayor y menor de cada foramen fisiológico mediante el programa Motic Images plus 2.0 ML. La forma de los forámenes fue determinada de acuerdo a la diferencia entre diámetro mayor y menor, clasificándose como redondo, oval o irregular. Un total de 174 forámenes fisiológicos fueron analizados. El promedio del diámetro menor y mayor fue entre $0,24-0,33 \mathrm{~mm}$ en primeros molares maxilares y entre $0,25-0,33 \mathrm{~mm}$ en primeros molares mandibulares. En molares maxilares, la forma del foramen más común fue la oval (50\%), luego irregular (32\%) y redonda (18\%). En molares mandibulares, la forma oval también fue la más frecuente (59\%), seguida por la irregular (23\%) y redonda (18\%). Los hallazgos de este estudio en relación a morfología de los forámenes fisiológicos apicales en primeros molares, permite al operador facilitar la elección de instrumentos del calibre adecuado para realizar con éxito la terapia endodóntica.

PALABRAS CLAVE: Foramen fisiológico; Contricción apical; Ápice radicular; Diámetro apical; Morfología foraminal; Primer molar permanente.

\section{REFERENCES}

Arora, S. \& Tewari, S. The morphology of the apical foramen in posterior teeth in a North Indian population. Int. Endod. J., 42(10):930-9, 2010.
Blaskovic-Subat, V.; Smojver, I.; Maricic, B. \& Sutalo, J. A computerized method for the evaluation of root canal morphology. Int. Endod. J., 28(6):290-6, 1995. 
Briceño, M.; El-Sayed, M. A. \& Willershausen-Zonnchen, B. Morphology of the physiological foramen: I. Maxillary and mandibular molars. J. Endod., 30(5):321-8, 2004

Dummer, P. M.; McGinn, J. H. \& Rees, D. G. The position and topography of the apical canal constriction and apical foramen. Int. Endod. J., 17(4):192-8, 1984.

Fan, B.; Yang, J.; Gutmann, J. L. \& Fan, M. Root canal systems in mandibular first premolars with C-shaped root configurations. Part I: Microcomputed tomography mapping of the radicular groove and associated root canal cross-sections. J. Endod., 34(11):1337-41, 2008.

Gani, O. \& Visvisian, C. Apical canal diameter in the first upper molar at various ages. J. Endod., 25(10):689-91, 1999

Hassanien, E. E.; Hashem, A. \& Chalfin, H. Histomorphometric study of the root apex of mandibular premolar teeth: an attempt to correlate working length measured with electronic and radiograph methods to various anatomic positions in the apical portion of the canal. J. Endod., 34(4):408-12, 2008.

Hülsmann, M. \& Schäfer, E. Apical patency: fact and fiction-a myth or a must? A contribution to the discussion. Endo, 3(4):285$307,2009$.

Jeong, H.; Park, S. J.; Park, S. H. \& Choi, G. W. Morphology of the apical root canal system in Korean mandibular first molar. J. Korean Acad. Conserv. Dent., 34(2):137-44, 2009.

Martos, J.; Lubian, C.; Silveira, L. F.; Suita de Castro, L. A. \& Ferrer Luque, C. M. Morphologic analysis of the root apex in human teeth. J. Endod., 36(4):664-7, 2010

Meder-Cowherd, L.; Williamson, A. E.; Johnson, W. T.; Vasilescu, D.; Walton, R. \& Qian, F. Apical morphology of the palatal roots of maxillary molars by using micro-computed tomography. J. Endod., 37(8):1162-5, 2011.

Morfis, A., Sylaras, S. N., Georgopoulou, M., Kernani, M., \& Prountzos, F. Study of the apices of human permanent teeth with the use of a scanning electron microscope. Oral Surgery, Oral Medicine, Oral Pathology, 77(2):172-6, 1994.

Olson, D. G.; Roberts, S.; Joyce, A. P.; Collins, D. E. \& McPherson, J. C. 3rd. Unevenness of the apical constriction in human maxillary central incisors. J. Endod., 34(2):157-9, 2008.

Ordinola-Zapata, R.; Bramante, C. M.; Villas-Boas, M. H.; Cavenago, B. C.; Duarte, M. H. \& Versiani, M. A. Morphologic micro-computed tomography analysis of mandibular premolars with three root canals. J. Endod., 39(9):1130-5, 2013.

Ponce, E. H. \& Vilar Fernández, J. A. The cemento-dentino-canal junction, the apical foramen, and the apical constriction: evaluation by optical microscopy. J. Endod., 29(3):214-9, 2003.
Prabhakar, J.; Priya, M. S.; Doss, L. J. T. \& Sukumaran, V. G. Piecewise Straight Line Approximation of Curve Existing in Slightly Curved Mesiobuccal Root Canal of Mandibular First Molar: A Radiographic Investigation. Int. J. Morphol., 31(1):131-5, 2013.

Saini, H. R.; Tewari, S.; Sangwan, P.; Duhan, J. \& Gupta, A. Effect of different apical preparation sizes on outcome of primary endodontic treatment: a randomized controlled trial. J. Endod., 38(10):1309-15, 2012.

Vertucci, F. J. Root canal morphology and its relationship to endodontic procedures. Endod. Top., 10(1):3-29, 2005.

\author{
Correspondence to: \\ Jaime Abarca \\ Facultad de Odontología, Universidad San Sebastián \\ Lago Panguipulli 1390 \\ Pelluco Alto \\ Puerto Montt \\ CHILE
}

Email: jabarcar@docenteuss.cl

Received: 29-03-2014

Accepted: 30-05-2014 